Canadian Journal of Higher Education

Revue canadienne d'enseignement supérieur

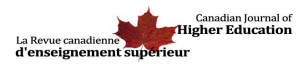

\title{
"Hungry for an Education": Prevalence and Outcomes of Food Insecurity Among Students at a Primarily Undergraduate University in Rural Nova Scotia
}

\author{
Lesley Frank
}

Volume 48, numéro 2, 2018

URI : https://id.erudit.org/iderudit/1057106ar

DOI : https://doi.org/10.7202/1057106ar

Aller au sommaire du numéro

\section{Éditeur(s)}

Canadian Society for the Study of Higher Education

ISSN

2293-6602 (numérique)

Découvrir la revue

Citer cet article

Frank, L. (2018). "Hungry for an Education”: Prevalence and Outcomes of Food Insecurity Among Students at a Primarily Undergraduate University in Rural Nova Scotia. Canadian Journal of Higher Education / Revue canadienne

d'enseignement supérieur, 48(2), 109-129. https://doi.org/10.7202/1057106ar
Résumé de l'article

Cet article traite de l'insécurité alimentaire parmi les étudiants d'une université rurale en Nouvelle-Écosse. Selon les résultats d'une enquête transversale réalisée en 2015, 38,1\% des étudiants avaient subi une insécurité alimentaire au cours des 12 mois précédents. L’insécurité alimentaire est associée statistiquement au logement, au financement des études, au régime de repas, et à l'année d'étude, ce qui contribue à des taux plus élevés de mauvaise santé générale et mentale et aux mauvais rendements scolaires. Les stratégies d'adaptation des étudiants affectent la réussite scolaire et la dette à long terme. Une analyse qualitative du manque d'argent pour l'alimentation révèle quatre thèmes: une incapacité de subvenir aux besoins primaires, une inquiétude chronique, une réduction du temps consacré aux études, et un impact sur la vie sociale. Les résultats témoignent de la nécessité de réévaluer les politiques de financement de l'enseignement postsecondaire au Canada afin de résoudre ces problèmes. 
Canadian Journal of Higher Education Revue canadienne d'enseignement supérieur

Volume 48, No. 2, 2018, pages 109 - 129

\title{
"Hungry for an Education": Prevalence and Outcomes of Food Insecurity Among Students at a Primarily Undergraduate University in Rural Nova Scotia
}

Lesley Frank Acadia University

\begin{abstract}
This paper reports on food insecurity among students attending a university in rural Nova Scotia. In 2015, 1,030 students completed an online, 38-item cross-sectional survey. The results report that $38.1 \%$ of students experienced food insecurity during the previous 12 months. Food insecurity was statistically associated with living arrangements, source of funds for schooling, meal plans, and year of study. Poor overall health, poor mental health, high stress, and poor academic performance were significantly higher for food-insecure students. Students employed multiple coping strategies, with implications for academic success and long-term debt. Qualitative analysis revealed four themes related to insufficient money for food: inability to cover basic needs, health-related outcomes of persistent worry, loss of time from learning, and impacts on social life. This research demonstrates the need to re-evaluate funding policies for post-secondary education in Canada to ensure students can afford the costs of basic needs and educational costs.
\end{abstract}

\section{Résumé}

Cet article traite de l'insécurité alimentaire parmi les étudiants d'une université rurale en Nouvelle-Écosse. Selon les résultats d'une enquête transversale réalisée en 2015, 38,1\% des étudiants avaient subi une insécurité alimentaire au cours des 12 mois précédents. L'insécurité alimentaire est associée statistiquement au logement, au financement des études, au régime de repas, et à l'année d'étude, ce qui contribue à des taux plus élevés de mauvaise santé générale et mentale et aux mauvais rendements scolaires. Les 
stratégies d'adaptation des étudiants affectent la réussite scolaire et la dette à long terme. Une analyse qualitative du manque d'argent pour l'alimentation révèle quatre thèmes: une incapacité de subvenir aux besoins primaires, une inquiétude chronique, une réduction du temps consacré aux études, et un impact sur la vie sociale. Les résultats témoignent de la nécessité de réévaluer les politiques de financement de l'enseignement postsecondaire au Canada afin de résoudre ces problèmes.

An increasing number of post-secondary students in Canada are struggling to afford post-secondary education, and evidence is mounting that student poverty is being realized in the existence and high usage of food banks on most Canadian university campuses (Ferguson, 2004). Tuition fees have risen by 238\% since 1991 (CAUT, 2014). Students are working more during the school year to afford higher education (Neill, 2015), and there is a mismatch between student loan funding and minimum wages in relation to the cost of tuition and basic needs (Ferguson, 2004). According to the Canadian Federation of Students-Nova Scotia (2004), insufficient funding affects vulnerable students the most, including Aboriginal and racialized students, and those with disabilities, deterring them from pursuing higher education. Other research has shown that international students attending university in Canada also experience unique challenges in affording their basic needs (Calder et al., 2016).

Food security has been measured in Canada since 2005 at the household level, consistent with the definition by the Food and Agriculture Organization of the United Nations (United Nations, 1996) as "all people, at all times, hav[ing] physical and economic access to sufficient, safe, and nutritious food to meet their dietary needs and food preferences for an active and healthy life." The United Nations' (1996) definition of food security covers four pillars of security: access, availability, utilization, and stability. In Canada, food security and food insecurity are measured using the Household Food Security Survey Module (HFSSM), administered as part of the Canadian Community Health Survey (CCHS), focusing "on self-reports of uncertain, insufficient, or inadequate food access, availability and utilization due to limited financial resources, and the compromised eating patterns and food consumption that may result" (Statistics Canada, 2010). Therefore, in Canada, the measurement of food insecurity has a strong focus on food affordability and is defined as being when access to food is inadequate or insecure due to financial constraints (Tarasuk, Mitchell, \& Dachner, 2016). Research on the prevalence of Canadian household food insecurity indicates that in 2014, 12\% of Canadian households were food insecure, representing 3.2 million people. The highest provincial rate of household food insecurity was in Nova Scotia (15.4\%) (Tarasuk et al., 2016).

Although there is considerable research on the food and eating practices of post-secondary students (Branen \& Fletcher, 1999; Chapman, Melton, \& Hammond, 1998; Garcia, Sykes, Matthews, Martin, \& Leipert, 2010; House, Su, \& Levy-Milne, 2006; McCarthy \& Sabry, 1973; Small, Bailey-Davis, Morgan, \& Maggs, 2013) and health-related outcomes of various eating practices within educational environments in Canada and the United States (Barker \& Galambos, 2007; Edmonds et al., 2008; Provencher et al., 2009), the pervasiveness of hunger and food insecurity for students and the related short- and longterm negative health, social, and educational outcomes have received less attention. 
Research on food insecurity among post-secondary student populations outside of Canada, predominantly from the United States (Bruening, Brennhofer, van Woerden, Todd, \& Laska, 2016; Chaparro, Zaghloul, Holck, \& Dobbs, 2009; Goldrick-Rab, Richardson, \& Hernandez, 2017; Maroto, Snelling, \& Linck, 2014; Morris, Smith, Davis, \& Null, 2016; Patton-López, López-Cevallos, Cancel-Tirado, \& Vazquez, 2014; Silva et al., 2015) and Australia (Gallegos, Ramsey, \& Ong, 2014; Hughes, Serebryanikova, Donaldson, \& Leveritt, 2011; Micevski, Thornton, \& Brockington, 2014), has shown a higher prevalence of student food insecurity compared to that of the general population.

The early published research on food insecurity among Canadian post-secondary students focused on the characteristics and experiences of campus food bank users as opposed to campus-wide food insecurity prevalence (Farahbakhsh et al., 2015; Meldrum \& Willows, 2006; Nugent, 2011). Campus-specific studies across Canada have been conducted recently, yet it is difficult to compare the results due to differing conceptualizations of food insecurity, data collection tools, and sampling methods. All Canadian studies to date, however, have reported high rates of food insecurity among these populations regardless of province and location compared to the general Canadian population. For example, $35.3 \%$ of respondents at the University of Manitoba were classified as food insecure (Entza, Slaterb, \& Desmarais, 2017), and 39.5\% of students at the University of Saskatchewan (Olauson, Engler-Stringer, Vatanparast, \& Honoski, 2018), and 37.2\% at St. Francis Xavier University (Reynolds, Johnson, Jameison, \& Mawhinney, 2018). Additionally, Meal Exchange, a national registered charity that supports students to develop innovative solutions to address hunger, food insecurity, and sustainability on their campuses, released the results of a study into the public domain that measured food insecurity on five urban Canadian campuses, reporting food insecurity rates ranging from $25.7 \%$ at the University of Calgary to $46 \%$ at Dalhousie University (Silverthorn, 2016). ${ }^{1}$

This paper reports on food insecurity research conducted in 2015 among students at Acadia University, a rural, primarily undergraduate university in Nova Scotia. The objective was to measure the prevalence, dynamics, and health and educational outcomes of student food insecurity. Acadia University is a residential university, meaning that the institution houses a considerable proportion of the student body on campus $(33.5 \%$ at the time of the study) in owned residences where the purchase of a full meal plan (unlimited daily meals for either five or seven days) is required. Nova Scotia citizens make up $54.9 \%$ of the student body, and approximately half (49.5\%) of these students come from surrounding rural areas. While research shows that the majority of Canadian university students attend university within 80 kilometres of where they attended high school (Frenette, 2004), for rural areas the closest university is often outside this range, making remaining at home with parents to minimize costs unrealistic, particularly considering the shortage of public transportation. Only $16.5 \%$ of the Acadia University campus population originates from one of the two closest counties. Therefore, this student body, rather than being made up of students who could feasibly live at home with family, is primarily made up of those living either in campus residences (with full meal plans) or in surrounding off-campus market rental options.

During the 2014-15 academic year, average undergraduate tuition fees in Nova Scotia were $\$ 6,440-\$ 481$ more than the national average of $\$ 5,959$ and among the highest in the country. Undergraduate tuition fees in Nova Scotia increased by $17.2 \%$ from $2010-11$ to 2015-16 (Statistics Canada, 2011). The high cost of tuition, along with the high prevalence 
of food insecurity among all Nova Scotians, suggests that university students in Nova Scotia may be at considerable risk of food insecurity. This is particularly concerning considering recent projections of increased costs of post-secondary education across Canada (MacDonald \& Shaker, 2014), which may undermine the potential of educational obtainment as a mechanism of income security in the future, particularly for low-income families.

\section{Methods}

A collaborative process was used to design a cross-sectional online survey in the fall of 2014, involving researchers at Acadia University and the University of Saskatchewan. The survey was adapted from one created by Dr. Noreen Willow's team at the University of Alberta, which measured the food security status, food insecurity coping strategies, and characteristics and experiences of clients of the campus food bank (Meldrum \& Willows, 2006). The survey was piloted and administered at both the University of Saskatchewan and Acadia University using separate online platforms. This paper reports on results from the Nova Scotia campus only. ${ }^{2}$

The Acadia University Research Ethics Board approved the study in December 2014 (REB 14-78). The campus student services office recruited respondents using an all-student email distribution list. The email (and two reminder emails) went to all students $(N=3916)$, containing a link to direct them to the survey webpage. Data were collected over two weeks in March 2015. The total number of respondents was 1,030, constituting a response rate of $26.3 \%$. Data were collected from students living both in universitysponsored residences and in off-campus locations (both the local rental market and those living at home with family).

\section{Measures}

The 38-item survey included the validated 10-item (adult) Household Food Security Survey Module (HFSSM) from the Canadian Community Health Survey (Health Canada, 2004), adapted to a student population. The HFSSM measures "uncertain, insufficient or inadequate food access, availability and utilization due to limited financial resources, and the compromised eating patterns and food consumption that may result" (Health Canada, 2004). Adaptations in wording were made to better reflect typical student living arrangements, by asking respondents to consider their own experiences and those of other people in their dwelling with whom they routinely shared food. This was to acknowledge that students often live with other students yet frequently maintain independent food practices and expenses. The HFSSM is an 18-measure module, adapted from the United States Department of Agriculture (USDA) Household Food Security Survey Module, which measures the food security situation in a household over the last 12 months (10 questions focus on the experiences of adults in the household, and eight questions are about children's experiences). The current study utilized the 10 adult questions only. The survey also contained questions to measure demographic associations of food security status, potential outcomes identified by the literature in the areas of health and academics, and questions about the strategies students employed when they ran out of money for food. An open-ended question was included that probed for the quality of students' university experience due to a lack of money for food, and another for strategies used to access food when students did not have enough money. 


\section{The Sample}

Table 1 displays comparisons of the sample demographics $(\mathrm{n}=1030)$ with the total student body using available administrative date provided at the time of data collection $(\mathrm{N}=3916)$. Table 2, presented in the results, provides a more complete report of the sample demographics, showing that respondents were primarily undergraduates, attending full-time, and had a mean age of 21 years. About two-thirds of the respondents lived offcampus, the majority living with roommates. Only $6.6 \%$ lived at home with family. Very few of the respondents were parents. Government student loans (29.7\%) were the leading source for paying for university. Table 1 displays that there was no statistical difference between the sample and population concerning year of study. A moderate statistically significant difference was found concerning gender, whereby there was a higher percentage of female students ( $16.2 \%$ difference) in the sample. While females experience a disproportionate level of food insecurity in Canada, in Nova Scotia food insecurity is in fact higher among males in the age group 20-34 (Statistics Canada, 2013). All other demographic factors for which there was administrative data (living arrangement, international status, Aboriginal status, level of study, full-time status, loan status), showed weak statistically significant differences (less than 10\%). The sample included a higher proportion of students receiving government student loans compared to the student body (4.1\% difference), indicating that there might be a higher percentage of lower income students in the sample, biasing the results toward higher rates of food insecurity. There was also a higher proportion of students living on-campus in the sample (6\% difference), which could bias the result toward under-reporting of food insecurity. ${ }^{3}$

\section{Analysis}

Food security status was calculated by summing the affirmative responses (coded 1) from the 10-item scale: $0-1$ indicate food secure, $2-5$ indicate moderately food insecure, and 6-10 indicate severely food insecure. This analysis did not include the concept of marginal food insecurity (indicated by the reporting of one food insecure condition). Known correlates of food security status in student populations were measured using descriptive statistics. Chi-square analysis was used to test for significance of association between food security status as the dependent variable and student demographic factors as the independent variables. Binary logistic regressions were conducted to measure the relative odds of four outcomes of food security status (fair/poor self-described overall health, high level of stress experienced most days, fair/poor self-described mental health, and lower grades overall). These regression models used a subgroup of students with high and low extremes on these outcomes, and the final models controlled for the covariates of gender, income source for paying for school, working status, year of study, living arrangement, Aboriginal status, and international status. Additionally, food-insecure students were isolated as a group to explore strategies used when there was a shortage of food. All quantitative data were analyzed using SPSS version 23.

Students' written comments provided insight about the complexity of food insecurity (both contributors and outcomes) in this population and environment. Students responded to a question about how their university experience may have been affected by the lack of money for food. Four key themes were identified: (1) attribution of financial 
Table 1: Sample and population comparisons

\begin{tabular}{|c|c|c|c|c|}
\hline & $\begin{array}{l}\text { Student Population } \\
\quad(N=3916)+\end{array}$ & $\begin{array}{c}\text { Sample } \\
(n=1030) \\
\end{array}$ & \% Difference & $P$-value* \\
\hline \multicolumn{5}{|l|}{ Prevalence \% } \\
\hline \multicolumn{5}{|l|}{ Living Arrangement } \\
\hline On campus in residence & $33 \cdot 5$ & 39.5 & \multirow{2}{*}{6.0} & \multirow{2}{*}{.0003} \\
\hline Off campus & 66.5 & 60.4 & & \\
\hline \multicolumn{5}{|l|}{ Loan Status ${ }^{\dagger}$} \\
\hline Has government student loan & 36.0 & 40.1 & \multirow{2}{*}{4.1} & \multirow{2}{*}{.0161} \\
\hline No government student loan & 64.0 & 59.9 & & \\
\hline \multicolumn{5}{|l|}{ Student Level } \\
\hline Undergraduate & 89.0 & 95.8 & \multirow{2}{*}{6.8} & \\
\hline Graduate & 11.0 & 4.2 & & .0001 \\
\hline \multicolumn{5}{|l|}{ Year of Study } \\
\hline 1st year & 27.8 & 28.6 & 0.8 & 6108 \\
\hline 2nd year & 26.4 & $25 \cdot 4$ & 1.0 & .5161 \\
\hline 3rd year & 23.1 & 22.3 & 0.8 & .5869 \\
\hline $4^{\text {th }}$ year & 18.8 & 20.6 & 1.8 & .0667 \\
\hline $5>$ years & 3.4 & 3.1 & 0.3 & .6334 \\
\hline \multicolumn{5}{|l|}{ Gender } \\
\hline Male & 40.5 & $25 \cdot 3$ & \multirow{2}{*}{16.2} & \multirow{2}{*}{.0001} \\
\hline Female & 59.5 & 74.1 & & \\
\hline \multicolumn{5}{|l|}{ Aboriginal $\neq$} \\
\hline Yes & .08 & $4 \cdot 7$ & \multirow{2}{*}{4.62} & \multirow[b]{2}{*}{.0001} \\
\hline No & 99.92 & $95 \cdot 3$ & & \\
\hline \multicolumn{5}{|l|}{ Full/Part-time Status } \\
\hline Full-time & 88.2 & $97 \cdot 4$ & \multirow{2}{*}{9.2} & \multirow[b]{2}{*}{.0001} \\
\hline Part-time & 11.8 & 2.6 & & \\
\hline \multicolumn{5}{|l|}{ International } \\
\hline Yes & 10.8 & 8.1 & \multirow{2}{*}{2.73} & \multirow[b]{2}{*}{.0102} \\
\hline No & 89.2 & 91.9 & & \\
\hline
\end{tabular}


struggle to insufficient student loan funding, insufficient earnings, or parents' inability to support them financially; (2) persistent worry about not having enough money for food and health-related outcomes; (3) concerns over spending "too much time" meeting basic needs rather than focusing on learning (primarily through working in paid employment alongside schooling); and (4) impacts on social life.

\section{Results}

The overall prevalence of food insecurity among students was $38.1 \%$ (23.9\% were moderately food insecure and $14.2 \%$ were severely food insecure; Table 2). ${ }^{4}$ Chi-square analysis showed that food security status was statistically associated with living arrangements, having a meal plan, the primary source of income used to pay for educational costs, working status, and year of study. Students living alone off campus or with roommates were more likely to be food insecure than those living at home or on campus. In fact, half (49.9\%) of the students living off campus-alone, with roommates, or with spouses and/ or children-were either moderately or severely food insecure (not shown in Table 2). Oncampus students, all of whom are required to purchase a meal plan, were the least likely to be food insecure (24.9\%), as were first-year students (28.0\%), which is not surprising, as they make up the majority of on-campus students. Students who were paying their educational costs primarily with their own waged employment were the most likely to be food insecure, followed by those paying with loans (bank and government loans). The least likely to be food insecure were students whose education was being paid for by their parents or their own personal savings. Approximately half of students with government student loans or bank loans were food insecure. Additionally, the rate of food insecurity increased by year of study, and, though not statistically significant, it was higher for graduate students, Aboriginal, international, and newcomer students.

Table 2: Food security status by sociodemographic characteristics of students

\begin{tabular}{|c|c|c|c|c|c|}
\hline & All & $\begin{array}{c}\text { Food } \\
\text { Secure }\end{array}$ & $\begin{array}{c}\text { Moderately } \\
\text { Food } \\
\text { Insecure }\end{array}$ & $\begin{array}{l}\text { Severely } \\
\text { Food } \\
\text { Insecure }\end{array}$ & $P$-value \\
\hline Prevalence \% & 100 & 61.9 & 23.9 & 14.2 & \\
\hline \multicolumn{6}{|l|}{ Full/Part-time Status $(n=1030)$} \\
\hline Full-time & $97 \cdot 4$ & 62.0 & 23.7 & $14 \cdot 3$ & \\
\hline Part-time & 2.6 & 59.3 & 29.6 & 11.1 & .741 \\
\hline \multicolumn{6}{|l|}{ Living Arrangement ( $n=1028$ ) } \\
\hline Residence & 39.5 & 76.4 & $15 \cdot 5$ & 8.1 & \\
\hline Off campus alone & 7.1 & 50.7 & 32.9 & 16.4 & \\
\hline Off campus with roommates & 36.9 & 50.5 & 28.9 & 20.5 & \\
\hline Off campus with family of origin & 6.6 & 69.1 & 27.9 & 2.9 & \\
\hline $\begin{array}{l}\text { Off campus with spouse and/or } \\
\text { child(ren) }\end{array}$ & 9.8 & 50.5 & 28.7 & 20.8 & $<.001$ \\
\hline
\end{tabular}




\begin{tabular}{|c|c|c|c|c|c|}
\hline & All & $\begin{array}{c}\text { Food } \\
\text { Secure }\end{array}$ & $\begin{array}{c}\text { Moderately } \\
\text { Food } \\
\text { Insecure }\end{array}$ & $\begin{array}{l}\text { Severely } \\
\text { Food } \\
\text { Insecure }\end{array}$ & $P$-value \\
\hline \multicolumn{6}{|c|}{ Primary Source of Income $(n=1017)$} \\
\hline Student loan & 29.7 & 50.8 & 28.2 & 20.9 & \\
\hline Bank loan & 4.1 & 47.6 & 21.4 & 21.4 & \\
\hline Employment & 9.6 & 44.0 & 37.0 & 24.0 & \\
\hline Family & 28.5 & 70.2 & 19.7 & 10.0 & \\
\hline Personal savings & 18.0 & $74 \cdot 5$ & 18.5 & 7.1 & \\
\hline Scholarship/TA & 10.0 & 71.3 & 17.8 & 10.9 & $<.001$ \\
\hline \multicolumn{6}{|l|}{ Currently Working $(n=1030)$} \\
\hline Yes & 35.8 & 56.9 & 26.0 & 17.1 & \\
\hline No & 64.2 & 64.8 & 22.7 & 12.6 & .033 \\
\hline \multicolumn{6}{|l|}{ Year of Study $(n=1026)$} \\
\hline 1st year & 27.8 & 72.0 & 19.6 & 8.4 & \\
\hline 2nd year & 26.4 & 61.8 & 25.0 & 13.2 & \\
\hline 3rd year & 23.1 & 56.3 & 25.2 & 18.5 & \\
\hline 4th year & 18.8 & 56.7 & $25 \cdot 3$ & 18.0 & \\
\hline $5>$ years & 3.4 & $44 \cdot 4$ & 36.1 & 19.4 & .001 \\
\hline \multicolumn{6}{|l|}{ Level of Study ( $n=1030)$} \\
\hline Undergraduate & 95.8 & 62.4 & 23.2 & $14 \cdot 3$ & \\
\hline Grad student & 4.2 & 54.8 & $35 \cdot 7$ & 9.5 & .158 \\
\hline \multicolumn{6}{|l|}{ Has Meal Plan $(n=1030)$} \\
\hline Yes & 41.9 & 75.1 & $15 \cdot 9$ & 9.0 & \\
\hline No & 58.1 & 52.4 & 29.8 & 18.0 & $<.001$ \\
\hline \multicolumn{6}{|l|}{ Gender $(n=1021)$} \\
\hline male & $25 \cdot 3$ & 60.8 & $23 \cdot 3$ & $15 \cdot 9$ & \\
\hline female & 74.7 & 62.3 & 24.2 & $13 \cdot 5$ & 0.645 \\
\hline \multicolumn{6}{|l|}{ Parent Status $(n=1030)$} \\
\hline Does not have child(ren) & 98.3 & 62.1 & 23.6 & 14.3 & \\
\hline Has child(ren) & 1.7 & 52.9 & 41.2 & $5 \cdot 9$ & .199 \\
\hline \multicolumn{6}{|l|}{ Aboriginal ( $n=1030)$} \\
\hline Yes & 4.7 & $45 \cdot 7$ & 34.8 & 19.6 & \\
\hline No & $95 \cdot 3$ & 62.7 & 23.5 & 14.0 & 0.069 \\
\hline \multicolumn{6}{|l|}{ Newcomer $(n=1030)$} \\
\hline Yes & 6.5 & $53 \cdot 7$ & 26.9 & 19.4 & \\
\hline No & 93.5 & 62.5 & 23.8 & 13.9 & 0.309 \\
\hline \multicolumn{6}{|l|}{ International $(n=1030)$} \\
\hline Yes & 8.1 & 55.4 & 26.5 & 18.1 & \\
\hline No & 91.9 & 62.5 & 23.8 & 13.9 & 0.412 \\
\hline
\end{tabular}


Using a subgroup of students indicating upper and lower attributes of health status, logistic regression analysis shows that the odds of self-reported fair or poor overall health status was 3.39 times higher (95\% CI [2.09-5.50]) for moderately food insecure students, and 6.59 times higher (95\% CI [3.73-11.63]) for severely food insecure students, independent of sociodemographic factors (Table 3). Logistic regression models also show significantly higher odds of reporting fair/poor mental health status, and high levels of stress most days, for both moderately and severely food insecure students. Moderately food insecure students were more than twice as likely to report overall grades in the C, D, and $\mathrm{F}$ range than food-secure students, while severely food insecure students were over five times as likely to report poorer grades.

Table 3. Odds of high level of stress, ${ }^{*}$ overall fair/poor health, ${ }^{\dagger}$ fair/poor mental health, $\neq$ and low grades§ in relation to household food security status

\begin{tabular}{|c|c|c|c|c|}
\hline \multicolumn{5}{|c|}{ Odds Ratio (95\% CL) } \\
\hline & Unadjusted & $P$-value & Adjusted Model || & $P$-value \\
\hline \multicolumn{5}{|c|}{ Reports Fair/Poor Overall Health $(n=631)$} \\
\hline Food secure & 1.00 & & 1.00 & \\
\hline Moderately insecure & $2.79(1.82-4.29)$ & $<.001$ & $3.39(2.09-5.50)$ & $<.001$ \\
\hline Severely insecure & $5.16(3.11-8.54)$ & $<.001$ & $6.59(3.73-11.63)$ & $<.001$ \\
\hline \multicolumn{5}{|c|}{ High Level of Stress Most Days $(n=598)$} \\
\hline Food secure & 1.00 & & 1.00 & \\
\hline Moderately insecure & $2.84(1.68-4.82)$ & $<.001$ & $3.29(1.84-5.90)$ & $<.001$ \\
\hline Severely insecure & $3.47(1.73-6.96)$ & $<.001$ & $3.86(1.82-8.20)$ & $<.001$ \\
\hline \multicolumn{5}{|c|}{ Reports Fair/Poor Mental Health $(n=689)$} \\
\hline Food secure & 1.00 & & 1.00 & \\
\hline Moderately insecure & $2.12(1.46-3.07)$ & $<.001$ & $2.25(1.48-3.41)$ & $<.001$ \\
\hline Severely insecure & $2.90(1.87-4.51)$ & $<.001$ & $2.90(1.76-4.78)$ & $<.001$ \\
\hline \multicolumn{5}{|c|}{ Reports Lower Grades Overall $(n=652)$} \\
\hline Food secure & 1.00 & & 1.00 & \\
\hline Moderately insecure & $2.16(1.41-3.30)$ & $<.001$ & $2.57(1.56-4.23)$ & $<.001$ \\
\hline Severely insecure & $4.18(2.51-6.95)$ & $<.001$ & $5.84(3.14-10.84)$ & $<.001$ \\
\hline
\end{tabular}

* Compares those indicating quite a bit and extremely stressful to those indicating not at all stressful or not very stressful

+ Compares those indicating fair and poor overall health to those indicating excellent and very good health

* Compares those indicating fair and poor mental health to those indicating excellent and very good mental health

$\S$ Compares those with primarily A grades overall to those with primarily Cs, Ds, and Fs

II Adjusted for gender, income source paying for school, working status, year of study, living arrangement, Aboriginal status, and international status 
Food-insecure students employed several strategies to access food when they ran out of money (Figure 1). Even though there is a community food bank adjacent to the university (but no on-campus food bank at the time of the study), only $1 \%$ of students sought help from charity-based food programs. The most common response to running out of food was to borrow money from family and friends (58.2\%), followed by using credit cards to purchase food (55.1\%). Over a third of food-insecure students indicated that they went to campus events to access free food, and $6.1 \%$ indicated that they stole food. Students also reported they used a variety of strategies to increase available food dollars throughout the year, some of which had the potential to negatively impact academics, such as delaying the purchase of textbooks (48\%). As one student commented, "At the beginning of the year, I do not buy textbooks unless I absolutely need them because I like to have that extra money for groceries at the end of the year." Others sought employment (44.9\%), even though this took away time for school and, for some, made accessing the meal hall difficult. Other students applied for a loan or bursary, delayed bill payments, sold or pawned belongings, or gave up services such as telephone and Internet.

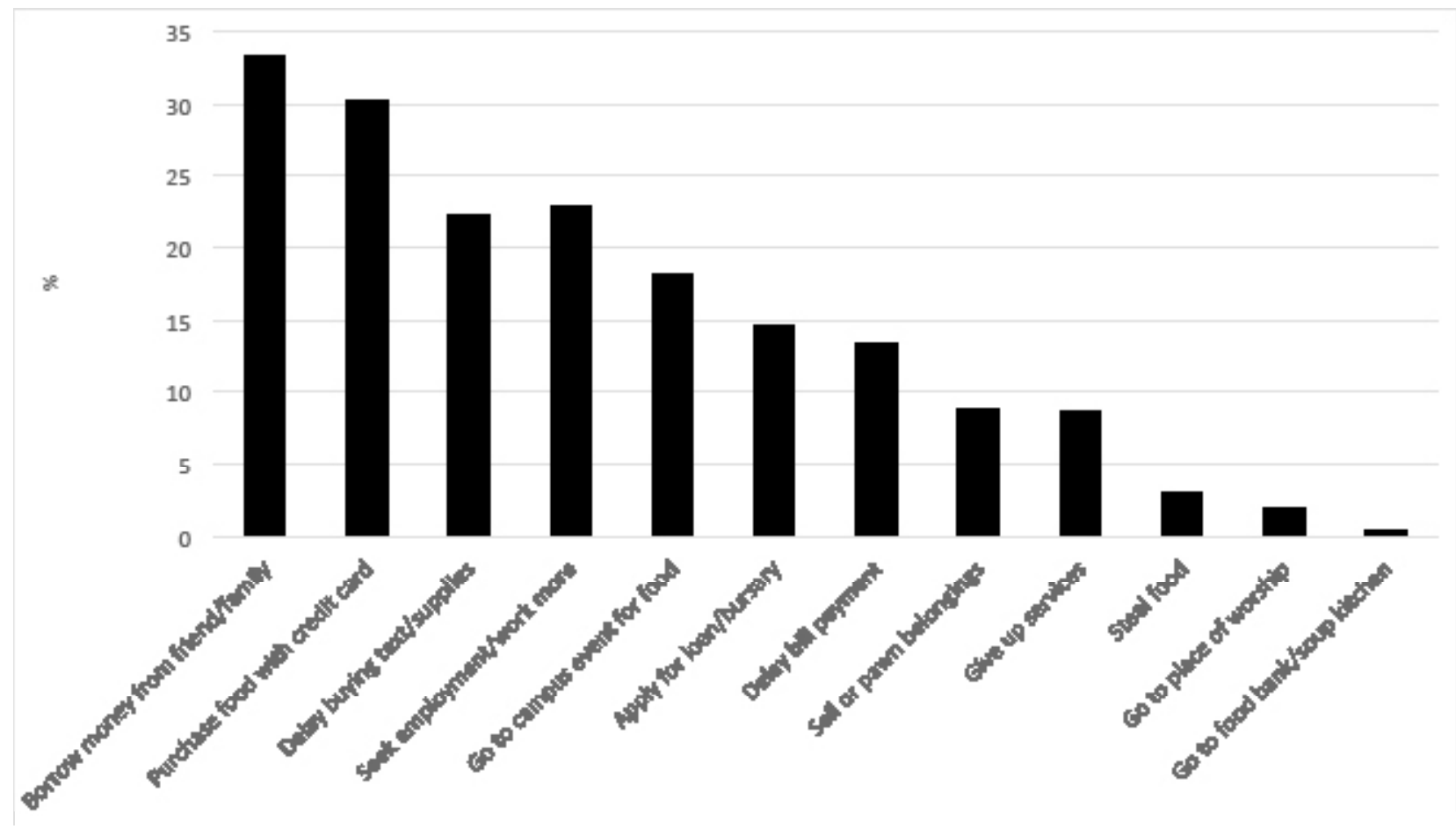

Figure 1. Strategies used by food-insecure students when they did not have enough money for food

\section{Discussion and Conclusion}

Overall, the results of the research showed a high rate of food insecurity among postsecondary students at this rural Nova Scotia campus. One student commented, "Being hungry for an education is not just a figurative saying." Another wrote, "If food wasn't a worry, university would be a lot better." Meldrum and Willows (2006) examined the relationship between the cost of food near the University of Alberta and the allotted funds 
for food provided by the Canada Student Loan Program, finding that such financial assistance was insufficient for a nutritionally adequate diet. The qualitative data from this survey support their finding. Several students commented about the inadequacy of their loans, one saying, "I don't find that student loans approximate very well the cost of living." Comments stressed both education and food affordability issues, as one student wrote,

Money shouldn't be an issue when it comes to feeding yourself, but the fact that this place has the highest tuition ever, as well as the increasing food costs, every meal might as well be KD or Mr. Noodles because that's all that can be afforded.

Another student commented that the cost of post-secondary education was the main problem, saying, "I think a lot of [food affordability] has to do with the high cost of tuition and not enough money more than the cost of food, however."

Tuition in Nova Scotia is higher than the national average (Statistics Canada, 2011) and, as several students commented, the combined cost of tuition, residence, and meal plans leads to considerable debt for some. Several students stated that while they might be food secure now, they were "going into debt in order to eat and go to school"; thus, they anticipated financial and food insecurity upon leaving school. One student wrote, "I'm likely to have these problems in the future when it is time to pay off the debt," and another wrote, "I sometimes worry about the future because I am depending on loans for housing and food, which will eventually run out." The quantitative results suggest that living on campus with an unlimited meal plan in a dining hall had a protective effect against food insecurity. However, consistent with other studies (Chaparro et al., 2009; Gallegos et al., 2014), food insecurity was still found among students living in campus residences with meal provisions. Analysis of the qualitative comments of on-campus students suggests that accessing meal hall with work and class schedules was not always possible. This meant that students sometimes needed food off campus, with no money to purchase it. Also, some commented that personal dietary needs and perceived poor quality of food on campus forced them to access food elsewhere with little financial resources to do so. The cost of a meal plan was also a concern. As one student noted, "Those who do have to buy a meal plan pay an exorbitant amount. I feel with such high tuition, something as essential as food should be more affordable." Another student wrote, "Even when I lived in residence I found myself struggling to pay for the meal plan, it cost a lot more than I ate." Another student said, "Meal hall is too expensive! I may have stayed on campus for another year but I didn't want to pay that much money for food and go into even more debt."

The extent to which the high cost of living and eating on campus motivates students to move to off-campus housing (which requires independent food provisioning) is unknown. The data do show, however, that the rate of living and eating on campus decreases with year of study. About $75 \%$ of the first-year respondents, but only $52.6 \%$ of second-year respondents, $15.5 \%$ of third-year respondents, and $7.8 \%$ of fourth-year respondents lived on campus. Some students did comment that living in rental market housing in the town was a strategy used to lessen debt and manage costs. This allowed for paying housing and food costs throughout the year with the help of paid employment. However, this research, consistent with other research (Chaparro et al., 2009; Hughes et al., 2011; Micevski et al., 2014), shows that the reality of rental market housing, particularly in a rural university town, resulted in even higher rates of food insecurity. Echoing other studies (Gallegos 
et al., 2014; Silva et al., 2015), the results reveal that food insecurity rates increase by year of study, thus highlighting a potential problem for student retention and ultimately educational obtainment. Furthermore, working students experienced higher rates of food insecurity than non-working students. Purchasing one's own food was also compromised by rurality and limited affordable food retail outlets. Several students commented on this, one saying, "Being in an isolated community where the only grocery store is too expensive and not having a car makes it harder to get food."

Students living at home with their families of origin were not immune to food insecurity, as one-third reported they were food insecure. This is not surprising considering the high rate of household food insecurity in Nova Scotia (Tarasuk et al., 2016) and the economic strain placed on parents when supporting children through university. As one student explained, "My father is unable to work due to disability and my mother works two jobs to support my family. I feel guilty asking my mother for money. I know she finds it hard." Another wrote, "My family is poor, I'm surviving on a student loan that does not give me any extra money for food after all my university expenses have been paid." The high rate of food insecurity among students who live at home highlights the complexity of determining the extent to which student food insecurity is related to educational factors or rooted in current family income dynamics of the local population. Regardless of the origins, however, the barrier to educational success remains problematic.

Students expressed persistent worry about not having enough money for food. One student wrote, "I find it really limits you to what you can do if you are constantly worrying about where your next meal is going to come from." Another wrote, "Worrying about money for food/rent causes me more stress than school ever has." Another student said, "I feel a lot of shame when I do not have money for food."

The quantitative data reported higher odds of self-reported poor health status, poor mental health, and high levels of stress. Students commented that feelings of worry, stress, and shame, and altered food consumption due to lack of money lead to poor mental and physical health outcomes. Several students indicated physical outcomes, saying they had trouble sleeping, had low levels of energy, weight loss or gain, and mood changes. One student wrote, "The less food I had, the less energy I had which deeply affected my motivation for school work." Other students stressed negative mental health outcomes because of lack of money for food, but often negative outcomes were multiple and interrelated; as one student wrote, "I can't afford to eat well balanced meals (not like I would have the time to anyway, because I work almost every night), so my physical health suffers. I also don't have time to go to the gym or run (I did every day in the summer) because I have to work so much. I often can't afford to go out with friends to a pub, so my social life suffers, which breaks down support networks and affects mental health. It's a vicious circle."

While students employ multiple strategies to deal with money shortages for food, one student said, "All these strategies do is add to stress," and several students worried about their use of credit cards to buy food, one writing, "I have gone into quite a lot of debt to feed myself. Currently my Visa is very full." Others resorted to stealing, one commenting that "I don't like stealing [food], but when I'm hungry and waiting on the little amount of money I get to buy food, I feel like I don't have another choice."

The quantitative results also showed a relationship between food insecurity and academics. Severely food insecure students were over five times as likely to report poorer 
grades compared to food-secure students. Qualitative comments expressed concerns over spending "too much time" meeting basic needs, taking time away for school. One student wrote, "What negatively impacts my grades is having to worry about everything and not focusing on my school work." Another wrote, "University is expensive and I find myself putting my energy toward worrying about expenses instead of school work." Several students explained how they needed to work to cover their basic needs, one writing,

Either I have to drop courses to work multiple jobs to afford living costs while attending university (which can negatively impact my GPA) or I do not work to focus on my studies, and ironically would lead to me being stressed and unfed.

The fact that food-insecure students faced a significantly higher risk of poorer health and academic outcomes is cause for concern, as food security, as well as the incomes that accompany higher levels of educational obtainment, are social determinants of health (Raphael, 2016). As one student commented, "The cost of university is ridiculously high, so depending on your situation as a student, you need to do whatever you have to in order to be sure you have enough to eat." Another said,

It's hard to study for a test when you're hungry. It's hard to focus in class when you had to skip breakfast. It takes a major toll on your overall social and mental health when you have to persistently tell your friends that you can't afford to go to get a coffee. Food is an essential to human life and it should not be a stressor in anyone's life, especially students.

Numerous other students, regardless of living arrangements, reported that their social life was affected by a lack of money for food, as they were unable to participate in the normal food routines of student life that included dining out or sharing meals together. As one student noted, "My social life was affected. I didn't want people over and have them see that I didn't have any food." Students mentioned that the food prices in restaurants in the town were largely unaffordable, and some reported having to miss out on social events and feeling lonely because of this. One student wrote, "Going out with friends is hard when you don't have money, so making friends and socializing becomes hard."

In conclusion, high rates of food insecurity were found in this population of students, linked to a heightened risk of negative health and academic outcomes. This research highlights the need for affordable post-secondary education for low-income students (CAUT, 2002). When the cost of education precludes food security, students are faced with unjust conditions of worry, stress, and hunger that make academic success challenging. Canadian students relying on loans to fund their education have an average debt load of \$27,000 after four years of university (Prairie Research Associates, 2015), with amounts highest for students who are citizens of Nova Scotia (Statistics Canada, 2014). This research shows that students relying on loans and employment as the primary means of paying for school experienced the highest levels of food insecurity compared to those relying on institutional scholarships or family. Yet food insecurity was found among students regardless of how they paid for school, highlighting the need for stronger public funding to finance higher education. We know that students from low-income families are less likely to pursue higher education (Statistics Canada, 2007), and individual means of paying for 
school that lead to debt are more likely to be avoided by low-income students (Callender \& Jackson, 2005). Current funding models for higher education in Canada that increasingly rely on decreased public expenditure, higher tuition fees, and increased individual and family financing (Nentwich, 2016) will continue to create barriers to higher education, particularly for low-income students, and, for those who do attend, may heighten the risk of food insecurity.

The prevalence of food insecurity at Acadia University (38.1\%) is similar to the rate reported at St. Francis Xavier University (37.2\%), another rural university in Nova Scotia. These rates are similar to rates reported at urban universities in Canada but lower than the rate reported at Dalhousie University (46\%) (a university in the urban capital of Nova Scotia). This suggests that food insecurity on university campuses is a problem in both rural and urban settings. The qualitative data from the survey, however, suggest that food insecurity may be experienced in unique ways in rural towns. Many students need to live away from family in what students considered to be high-cost residences or rental housing where, in either case, food was unaffordable. At Acadia University, more than half the student body is from Nova Scotia, and half of those are from surrounding rural areas. Despite marginally higher tuition compared to most other Nova Scotia institutions, for many rural students Acadia University is the closest and therefore potentially the most affordable option. Rural students are additionally burdened by the higher cost of food in rural Nova Scotia (Voices for Food Security in Nova Scotia, 2017).

Young people are instructed that education is the pathway to prosperity. While students' experiences of food insecurity may be short-lived while they are pursuing their education, if pursuing that education causes poverty, food insecurity, poor health and educational outcomes, and insurmountable debt, such experiences may extend well into the future. If so, education loses its power to improve the quality of life for a growing proportion of students, particularly if food insecurity prevents them from being able to complete their degrees. Post-secondary education is a predictor of improved outcomes for individuals and society, and economic barriers to education have the potential to perpetuate inequity in the Canadian population (Bryce, Iglesias, Pullman, \& Rogova, 2016). Therefore, it is important to consider the provision of supports that allow increased student retention for those who have academic potential but may not have the financial backing to make post-secondary education a reality. The results suggest that funding for student loans be evaluated to ensure that it keeps pace with the actual costs of basic needs and educational costs. Considering concerns about student debt, increased non-repayable grant support for low-income students may be one possible solution. Given the protective effect of campus meal plans on student food-insecurity rates, another potential solution would be more flexible and affordable meal plans for both on- and off-campus students. The mounting evidence of growing rates and associated negative outcomes of food insecurity in Canada reinforces the need to ensure that post-secondary education is a protective measure, not a contributor to this social problem.

\section{Limitations}

There are several limitations to this research. This study used a cross-sectional design that prevents causal relationships analysis. Also, the survey relied on self-reporting on health and academic questions, which could have resulted in bias. There is also potential 
bias due to self-selection as opposed to probability sampling (Bethlehem, 2009). This was a total-population-based survey that precluded the need for sampling; however, it is possible that the sample is not representative of the student body. Even though a high response rate improves the chances that the sample will better represent the population from which it is drawn, there may still be a problem of self-selection bias whereby those experiencing problems with food affordability were more motivated to respond. As mentioned, though, there was no statistically significant difference by year of study-only weak differences concerning living arrangements, international status, Aboriginal status, level of study, full-time status, and loan status-and a moderate overrepresentation of female respondents. These differences could potentially bias the results in divergent directions.

Another limitation is that the food situation questions from the Household Food Security Survey Module (HFSSM) reflect a time frame of 12 months; therefore, it is possible that some students might be reflecting on their experiences during the spring/summer months when living off campus. The time frame of student food insecurity during the calendar year may prompt different potential solutions.

Finally, this research relied on the Household Food Security Survey Module, a measurement of food insecurity that defines food insecurity as occurring when access to food is inadequate or insecure due to financial constraints (Tarasuk et al., 2016).

Students may be food insecure because of other structural reasons that make accessing and using food difficult. Qualitative comments suggest that structural factors such as limited grocery outlets and lack of transportation affected their access to food, as did the nature of student funding (paid in a lump sum at the beginning of the term), making long-term budgeting challenging and vulnerable to unexpected costs. It can be argued that adequate financial resources would solve such challenges, as students would be better able to respond, yet further research is needed to understand how these contributors of food insecurity are experienced. This, along with research that demonstrates the affordability of post-secondary education in relation to current educational and basic needs costs, based on a variety of funding arrangements, would contribute to our understanding of the reasons students are food insecure.

\section{Notes}

1. Campus prevalence studies to date vary on how food insecurity is measured. Most use some or all of the 10-item adult food security module from the HFSSM. Some measure "marginal food insecurity" in line with reporting from PROOF (an interdisciplinary research team that investigates household food insecurity in Canada and publishes annual reports using Statistics Canada data), while others use "moderate" and "severe" classifications only.

2. For the results from the University of Saskatchewan see Olauson, Engler-Stringer, Vantanparast, and Honoski (2018).

3. Specific student demographics within any given post-secondary institution may increase or decrease the risk of food insecurity regardless of student status, as student bodies may be constituted by individuals who possess known characteristics that increase the odds of food insecurity. For example, Canadians of Aboriginal identity are more likely to be food insecure (Tarasuk et al., 2016), yet the percentage of Aboriginal students in this sample (4.7\%) is similar to the percentage of Canadians of Aboriginal 
identity (4.3\%) (Statistics Canada, 2016a). New immigrants, also more likely to be food insecure (Tarasuk et al., 2016), make up 3.5\% of the Canadian population (Statistics Canada, 2016b). Newcomers were thus overrepresented in this survey (6.5\%). We also know that younger Canadians, those living in rental housing, and unattached individuals have higher rates of food insecurity (Tarasuk et al., 2016). These are characteristics more likely to be experienced by students. The odds of food insecurity due to student status, controlled for such factors, has not been reported on using the Canadian Community Health Survey. However, we do know that the rates of food insecurity measured by these factors individually show much lower rates of food insecurity when compared to similar demographic factors reported in this research. For example, $11.6 \%$ of unattached individuals in Canada and $18.7 \%$ of Canadians who do not own their dwelling are food insecure (Health Canada, 2017). In Nova Scotia, 16.5\% of people aged 20-34 were reported to be food insecure (Statistics Canada, 2013). Higher rates of food insecurity reported in this research (38.1\% of all students with the mean age of 21, approximately 50\% of students living off-campus alone or with roommates, and $36.5 \%$ of unattached students) suggest that other factors are at play: either student status or associated factors of student status yet to be explored.

4. Of the students, $13.7 \%$ were marginally food insecure. If marginal food insecurity is included in the prevalence, $51.3 \%$ of students are classified as experiencing some level of food insecurity. Considering off-campus students only, the rate is $61.1 \%$.

\section{Acknowledgements}

The author acknowledges Brittany Pulsifer (Acadia Sociology Masters student) for her work in the data collection phase of this project, and Duane Currie, (Institutional Research Officer), for compiling demographic data of the student population. The author also acknowledges Kate Ashley, and her students from the course FRAN3023 (Bases de la Traduction), Department of Language and Literature, Acadia University, for their interest and work providing French translation.

\section{References}

Barker, E. T., \& Galambos, N. L. (2007). Body dissatisfaction, living away from parents, and poor social adjustment predict binge eating symptoms in young women making the transition to university. Journal of Youth and Adolescence, 36(7), 904-911. https://doi. org/10.1007/s10964-006-9134-6

Bethlehem, J. (2009). Can we make official statistics with self-selection web surveys? Symposium 2008: Data collection: Challenges, achievements and new directions.

Ottawa, ON: Statistics Canada's International Symposium Series, Catalogue no. 11522-X. Retrieved from http://www.statcan.gc.ca/pub/11-522-x/2008000/article/10989eng.pdf

Branen, L., \& Fletcher, J. (1999). Comparison of college students' current eating habits and recollections of their childhood food practices. Journal of Nutrition Education, 31(6), 304-310. https://doi.org/10.1016/Soo22-3182(99)70483-70488 
Bruening, M., Brennhofer, S., van Woerden, I., Todd, M., \& Laska, M. (2016). Factors related to the high rates of food insecurity among diverse, urban college freshmen. Journal of the Academy of Nutrition and Dietetics, 116(9), 1450-1457. https://doi.org/10.1016/j. jand.2016.04.004

Bryce, C., Iglesias, R., Pullman, A., \& Rogova, A. (2016). Inequality explained: The hidden gaps in Canada's education system. Retrieved from https://www.opencanada. org/features/inequality-explained-hidden-gaps-canadas- education-system/

https://www.opencanada.org/features/inequality-explained-hidden-gaps-canadaseducation-system/

Calder, M., Richter, M., Mao, Y., Burns, K., Mogale, R., \& Danko, M. (2016). International students attending Canadian university: Their experiences with housing, finances, and other issues. Canadian Journal of Higher Education, 46(2), 92-110.

Callender, C., \& Jackson, J. (2005). Does the fear of debt deter students from higher education? Journal of Social Policy, 34(4), 509-540. https://doi.org/10.1017/ So04727940500913X

Canadian Federation of Students - Nova Scotia. (2014). Face the future: Postsecondary education. Halifax, NS: Author. Retrieved from http://cfs-ns.ca/wp-content/ uploads/sites/25/2014/o9/2014-09-17_FaceoftheFuture.pdf

CAUT. (2002). Access denied: The affordability of post-secondary education in Canada, 1857- 2002. CAUT Education Review, 4(1), 1-8. Retrieved from https://www.caut.ca/ docs/default-source/education-review/the-economics-of-access-the-fiscal-reality-ofpse-costs-for-low-income-families-(june-2006).pdf?sfvrsn $=0$

Chaparro, P. M., Zaghloul, S. S., Holck, P., \& Dobbs, J. (2009). Food insecurity prevalence among college students at the University of Hawai'i at Mānoa. Public Health Nutrition, 12(11), 2097-2103. https://doi.org/10.1017/S1368980009990735

Chapman, G., Melton, C, \& Hammond, G. (1998). College and university students' breakfast consumption patterns: Behaviours, beliefs, motivations and personal and environmental influences. Canadian Journal of Dietetic Practice and Research, 59(4), $176-182$.

Davis, B., \& Tarasuk, V. (1994). Hunger in Canada. Agriculture and Human Values, 11(4), 50-57. https://doi.org/10.1007/BF01530416

Edmonds, M. J., Ferreira, K. J., Nikiforuk, E. A., Finnie, A. K., Leavey, S. H., Duncan, A. M., \& Randall Simpson, J. A. (2008). Body weight and percent body fat increase during the transition from high school to university in females. Journal of the American Dietetic Association, 108(6), 1033-1037. https://doi.org/10.1016/j.jada.2008.03.002

Entza, M., Slaterb, J., \& Desmarais, A. (2017). Student food insecurity at the University of Manitoba. Canadian Food Studies, 4(1), 139-159. http://dx.doi.org/10.15353/cfs-rcea. v4i1.204

Farahbakhsh, J., Ball, G. D. C., Farmer, A. P., Maximova, K., Hanbazaza, M., \& Willows, N. D. (2015). How do student clients of a university-based food bank cope with food insecurity? Canadian Journal of Dietetic Practice and Research, 76(4), 200-203. http:// doi.org/10.3148/cjdpr-2015-020 
Ferguson, M. (2004). Campus hunger count 2004-Struggling to feed hope to Canada's students: Food banks emerge in response to student hunger. Ottawa, ON: Canadian Association of Food Banks and Canadian Alliance of Student Associations.

Frenette, M. (2004). Access to college and university: Does distance to school matter? Canadian Public Policy, 30(4), 427-443.

Gallegos, D., Ramsey, R., \& Ong, K. W. (2014). Food Insecurity: Is it an issue among tertiary students? Higher Education: The International Journal of Higher Education and Educational Planning, 67(5), 497-510. https://doi.org/10.1007/s10734-013-9656-2

Garcia, A. C., Sykes, L., Matthews, J., Martin, N., \& Leipert, B. (2010). Perceived facilitators of and barriers to healthful eating among university students. CanadianJournal of Dietetic Practice and Research, 71(2), e28-e33. https://doi.org/10.3148/71.2.2010.69

Goldrick-Rab, S., Richardson, J., \& Hernandez, A. (2017). Hungry and homeless in college: Results from a national study of basic needs insecurity in higher education. Washington, DC: ACCT. Retrieved from http://wihopelab.com/publications/hungryand-homeless-in-college-report.pdf

Health Canada. (2007). Canadian Community Health Survey, Cycle 2.2, Nutrition (2004)-Income-related household food security in Canada. Ottawa, ON: Office of Nutrition Policy and Promotion, Health Products and Food Branch, Health Canada, Report no. 4696.

Health Canada. (2017). Household food insecurity in Canada statistics and graphics (2011 to 2012). Ottawa, ON: Author. Retrieved from https://www.canada.ca/en/healthcanada/services/nutrition-science-research/food-security/household-food-securitystatistics-2011-2012.html\#s4.4House, J., Su, J., \& Levy-Milne, R. (2006). Definitions of healthy eating among university students. Canadian Journal of Dietetic Practice and Research, 67(1), 14-18. https:// doi.org/10.3148/67.1.2006.14

Hughes, R., Serebryanikova, I., Donaldson, K., \& Leveritt, M. (2011). Student food insecurity: The skeleton in the university closet. Nutrition \& Dietetics, 68(1), 27-32. https://doi.org/ 10.1111/j.1747-0080.2010.01496.x

MacDonald, E., \& Shaker, E. (2014). Tier for two: Managing the optics of provincial tuition fee policies. Ottawa, ON: Canadian Centre for Policy Alternatives. Retrieved from https://www.policyalternatives.ca/publications/reports/tier-two

Maroto, M. E., Snelling, A., \& Linck, H. (2014). Food insecurity among community college students: Prevalence and association with grade point average. Community College Journal of Research and Practice, 39(6), 515-526. https://doi.org/10.1080/106 68926.2013.850758

McCarthy, M. E., \& Sabry, J. H. (1973). Canadian university students' nutrition misconceptions. Journal of Nutrition Education, 5(3), 193-196. https://doi.org/10.1016/ SoO22-3182(73)80085-80088

Meldrum, L. A., \& Willows, N. D. (2006). Food insecurity in university students receiving financial aid. Canadian Journal of Dietetic Practice and Research, 691(6), 4346. https:// doi.org/10.3148/67.1.2006.43 
Micevski, D. A., Thornton, L. E., \& Brockington, S. (2014). Food insecurity among university students in Victoria: A pilot study. Nutrition \& Dietetics, 71(4), 258-264. https://doi.org/10.1111/1747-0080.12097

Morris, L. M., Smith, S., Davis, J., \& Null, D. B. (2016). The prevalence of food security and insecurity among Illinois University students. Journal of Nutrition Education and Behavior, 48(6), 376-382. https://doi.org/10.1016/j.jneb.2016.03.013

Neill, C. (2015). Rising student employment: The role of tuition fees. Education Economics, 23(1), 101-121.

Nentwich, F. (2016). Financing Canadian universities: Major changes since 1802. Canadian Journal of Educational Administration and Policy, 178.

Nugent, M. A. (2011). Journeys to the food bank: Exploring the experience of food insecurity among postsecondary students. (Masters Dissertation). University of Lethbridge Institutional Repository. Retrieved from https://www.uleth.ca/dspace

Olauson, C., Engler-Stringer, R., Vantanparast, H. \& Honoski, R. (2018). Student food insecurity: Examining barriers to higher education at the University of Saskatchewan. Journal of Hunger and Environmental Nutrition, 13(1), 19-27. https://doi.org/10.1080 /19320248.2017.1393365

Patton-López, M. M., López-Cevallos, D. F., Cancel-Tirado, D. I., \& Vazquez, L. (2014). Prevalence and correlates of food insecurity among students attending a midsize rural university in Oregon. Journal of Nutrition Education and Behavior, 46(3), 209-214. https://doi.org/10.1016/j.jneb.2013.10.007

Peng, A., \& Yang, L. (2010). Dividing time between work and study: Are tuition fees a factor? Canadian Journal of Higher Education, 4O(1), 13-29.

Prairie Research Associates. (2015). Graduating university student survey: Master report. Prepared for Canadian University Survey Consortium. Retrieved from http:// www.cusc-ccreu.ca/CUSC_2015_Graduating_Master\%2oReport_English.pdf

Provencher, V., Polivy, J., Wintre, M. G., Pratt, M. W., Pancer, S. M., Birnie-Lefcovitch, S., \& Adams, G. R. (2009). Who gains or who loses weight? Psychosocial factors among first-year university students. Physiology \& Behavior, 96(1), 135-141. https://doi. org/10.1016/j.physbeh.2008.09.011

Raphael, D. (Ed.). (2016). Social determinants of health: Canadian perspectives (3rd ed.). Toronto, ON: Canadian Scholars' Press.

Reynolds, E., Johnson, C., Jameison, J., \& Mawhinney, H. (2018). Prevalence and correlates of food insecurity among students attending a small, rural Canadian university. Canadian Journal of Dietetic Practice and Research, 79. https://doi-org.ezproxy.acadiau. ca:9443/10.3148/cjdpr-2018-004

Silva, M. R., Kleinert, W. L., Sheppard, A. V., Cantrell, K. A., Freeman-Coppadge, D. J., Tsoy, E., Roberts, T., \& Pearrow, M. (2017). The relationship between food security, housing stability, and school performance among college students in an urban university. Journal of College Student Retention: Research, Theory \& Practice, 19(3), 284-299. https://doi.org/10.1177/1521025115621918 
Silverthorn, D. (2016). Hungry for knowledge: Assessing the prevalence of student food insecurity on five Canadian campuses. Toronto, ON: Meal Exchange. Retrieved from https://mealexchange.app.box.com/v/hungryforknowledge

Small, M., Bailey-Davis, L., Morgan, N., \& Maggs, J. (2013). Changes in eating and physical activity behaviors across seven semesters of college. Health Education \& Behavior, 4O(4), 435-441. https://doi.org/10.1177/1090198112467801

Statistics Canada. (2007). Why are youth from lower-income families less likely to attend university? Evidence from academic abilities, parental influences, and financial constraints. Ottawa, ON: Statistics Canada, Catalogue no. 11Foo19MIE - No. 295. Retrieved from http://www.statcan.gc.ca/pub/11foo19m/11fo019m2007295-eng.htm

Statistics Canada. (2010). Household food insecurity, 2007-2008, Health Fact Sheets. Ottawa, ON: Statistics Canada. Retrieved from http://www.statcan.gc.ca/pub/82625-x/2010001/article/11162-eng.htm

Statistics Canada. (2011). Undergraduate tuition fees for full time Canadian students, by discipline, by province (Nova Scotia). Ottawa, ON: Statistics Canada. Retrieved from http://www.statcan.gc.ca/tables-tableaux/sum-som/lo1/csto1/educ5od-eng.htm

Statistics Canada. (2013). Table 105-O54-Household food insecurity, by age group and sex, Canada, provinces, territories, health regions (2013 boundaries) and peer groups. Ottawa, ON: Statistics Canada, CANSIM (data base). Retrieved from http:// www5.statcan.gc.ca/cansim/a47

Statistics Canada. (2014). Table 477-0o68- National Graduates Survey, student debt from all sources by province and level of study, every 5 years. Ottawa, ON: Statistics Canada, CANSIM (data base). Retrieved from http://www5.statcan.gc.ca/ cansim/a26?lang $=$ eng\&retrLang $=$ eng\&id $=4770068 \& \&$ pattern $=\&$ stByVal $=1 \& p 1=1 \& p 2=-$ $1 \&$ tabMode $=$ dataTable $\&$ csid $=$

Statistics Canada. (2016a). Aboriginal peoples in Canada: First Nations People, Métis and Inuit. Ottawa, ON: Statistics Canada, Catalogue no. 99-011-X2011001. Retrieved from http://www12.statcan.gc.ca/nhs-enm/2011/as-sa/99-011-x/99-011-x2011001-eng.pdf

Statistics Canada. (2016b). Immigration and ethnocultural diversity in Canada. Ottawa, ON: Statistics Canada, Catalogue no. 99-010-X2011001. Retrieved from http:// www12.statcan.gc.ca/nhs-enm/2011/as-sa/99-010-x/99-010-x2011001-eng.pdf

Tarasuk, V., Mitchell, A., \& Dachner, N. (2016). Household food insecurity in Canada, 2014. Toronto, ON: Research to identify policy options to reduce food insecurity (PROOF). Retrieved from http://proof.utoronto.ca

United Nations. (1966). International Covenant on Economic, Social and Cultural Rights. Geneva, Switzerland: Office of the United Nations High Commissioner for Human Rights (OHCHR). Retrieved from http://www.ohchr.org/EN/ProfessionalInterest/ Pages/CESCR.aspx

Voices for Food Security in Nova Scotia. (2017). Can Nova Scotians afford to eat healthy? Report on 2015 participatory food costing. Halifax, NS: Food Action Research Centre (FoodARC), Mount Saint Vincent University. Retrieved from https://foodarc.ca/ wp-content/uploads/2017/03/2016_Food_Costing_Report_LR_SPREADS.pdf 
Willows, N. D., \& Au, V. (2006). Nutritional quality and price of university food bank hampers. Canadian Journal of Dietetic Practice and Research, 67(2), 104-107. http:// doi.org/10.3148/67.2.2006.104

\section{Contact Information}

Lesley Frank

Department of Sociology

Acadia University

Lesley.frank@acadiau.ca

Lesley Frank is an Associate Professor in the Department of Sociology at Acadia University where she teaches research methods and courses in the sociology of food, health, and social policy. Her research focuses on food insecurity, health equity, and social justice, particularly in relation to families and children living in low-income circumstances. She is a Research Associate with the Canadian Centre for Policy Alternatives, and a longstanding author of the annual Nova Scotia Child and Family Poverty Report Card. 